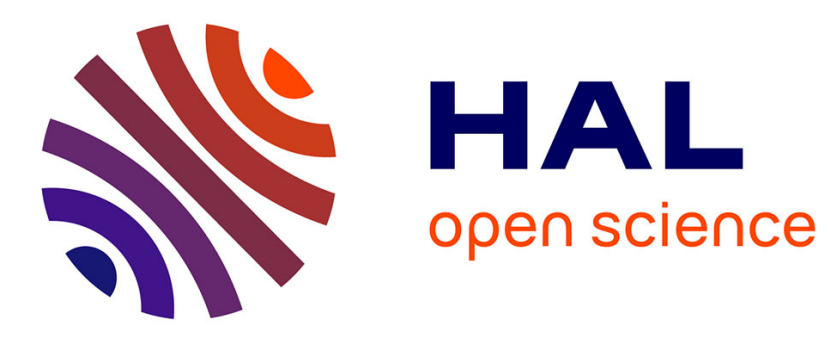

\title{
Environmental and Corporate Crimes
}

\author{
Laurent Mucchielli
}

\section{To cite this version:}

Laurent Mucchielli. Environmental and Corporate Crimes: The Case of Polluting Industries in France. Augusto Balloni; Raffaella Sette. Handbook of Research on Trends and Issues in Crime Prevention, Rehabilitation, and Victim Support, IGI Global, pp.283-296, 2020, 9781799812869. 10.4018/978-17998-1286-9.ch016 . halshs-02422489

\section{HAL Id: halshs-02422489 \\ https://shs.hal.science/halshs-02422489}

Submitted on 11 Feb 2020

HAL is a multi-disciplinary open access archive for the deposit and dissemination of scientific research documents, whether they are published or not. The documents may come from teaching and research institutions in France or abroad, or from public or private research centers.
L'archive ouverte pluridisciplinaire HAL, est destinée au dépôt et à la diffusion de documents scientifiques de niveau recherche, publiés ou non, émanant des établissements d'enseignement et de recherche français ou étrangers, des laboratoires publics ou privés. 


\title{
Environmental and corporate crimes : the case of polluting industries in France
}

\author{
Laurent MUCCHIELLI \\ CNRS, Aix-Marseille Université, LAMES, France
}

in A. Balloni \& R. Sette (eds.), Handbook of Research on Trends and Issues in Crime Prevention, Rehabilitation, and Victim Support, Hershey, IGI Global, p. 283-296

The issue of health disasters caused by human economic activities has been increasingly publicized since the 1970s, in connection with the emergence of ecology as a new philosophical and political trend in Western countries. Major accidents and other "disasters" that occur regularly (such as Seveso, Chernobyl, Fukushima or oil spills) have also led States and supranational bodies such as the European Union to increase the number of laws, control bodies and measurement tools. This set of public concerns and institutional mobilizations quickly boosted scientific research in the biomedical and climatological fields. Moreover, the lawyers soon took up a new world of constantly evolving national and international standards. An environmental law was thus established in the mid-1970s. The arrival of social sciences in this field is much later, at least in Europe (in the United States, a sociology of the environment is constituted as a sub-domain of the discipline since the end of the 1970s [Buttel, 1978 ; Catton, Dunlap, 1979]). However, a real dynamic is now at work at the beginning of the 21 st century. In France, it can be seen at work in political science, particularly in the study of these new public policies and new forms of activism, or in the analysis of the agenda setting of new public problems (e.g. Gilbert, Henry, 2009; Jouzel, 2012). Health sociology and occupational sociology have also integrated these new health and environmental safety issues (e.g. COllectif, 2010; Terssac, Mignard, 2011; Fournier, 2012; Thébaud-Mony et al., 2012).

More recently, sociologists have proposed linking these questions to those traditionally associated with the theme of "insecurity", by talking about health disasters affecting populations, but also about fraud and tax evasion ruining States, as well as "ignored insecurities" (Palidda, 2016). This chapter proposes to contribute to this new field of research in two ways. The first is to document the nature and extent of these health threats to populations. 
The second is to highlight the existence of delinquent practices (which will be defined as deliberate violations of legal norms) that sometimes play a major role in perpetuating these threats, following in the footsteps of Edwin Sutherland's research on the White Collar Crime (Spire, 2013; Lascoumes, Nagels, 2014; Mucchielli, 2014, 2015). More precisely, we will draw inspiration from research on Corporate Crime developed since the 1980s, one of whose branches soon made the link with environmental and health issues of interest to the Green criminology movement as it has developed since the early 1990s in England and the United States (see the first reports by Bottoms, 1994; and South, 1998). The fields of study covered by these issues are particularly broad and diverse (Hall et al., 2016). Turning to the case of France, we will limit ourselves here to examining the case of air pollution caused by road transport and industry, a major pollution in terms of health and the environment.

\section{Air pollution: the situation in France}

Santé Publique France (SPF) is the national public health agency created in April 2016, following the law of 26 January 2016 on the modernization of the health system, with the mission of "effectively protecting the health of populations". In June 2016, it published a report entitled Impacts of Chronic Exposure to Fine Particles on Mortality in Continental France, which is in line with the scientific work of the World Health Organization (WHO) and the European Environment Agency (EEA). This report provides a comprehensive overview of the extent and health effects of air pollution (fine particles of 2.5 micrometers), based on a study of all municipalities in metropolitan France in 2007-2008. These pollutions are defined as "a complex mixture composed of primary pollutants emitted directly by the sources of pollution (road traffic, industry, heating, agriculture...)". These include, for example, sulphur oxides, volatile organic compounds, particles, metals (lead, mercury, cadmium, etc.). Secondary pollutants not emitted directly from a source but resulting from chemical reactions in the atmosphere, such as ozone and nitrogen dioxide, are also considered.

This report first confirms that, "through various mechanisms including oxidative stress and inflammation, exposure to air pollution, particularly fine particulate matter, contributes to the development of chronic diseases such as cardiovascular, respiratory or neurological diseases, and cancers. It also promotes reproductive and developmental disorders in children. It also aggravates the symptoms of diseases in people suffering from chronic diseases" (Santé Publique France, 2016). The agency estimates that air pollution is responsible for about "48,000 deaths per year, which corresponds to $9 \%$ of mortality in France and a loss of life expectancy at 30 
years that can exceed 2 years". This is the second leading cause of death after tobacco (about 78,000 deaths per year), "but we choose to smoke or not. However, we do not choose the air we breathe. Finally, this health disaster would have a total annual cost of around 100 billion euros to French public finances, according to the report of a parliamentary survey in 2015 (Sénat, 2015).

In addition to the pollution caused by the combustion of firewood by private individuals, three main economic sectors are responsible for most of the air pollution: the road transport sector, the industrial sector and agriculture. We will focus here on the first two, which are the two most important.

\section{Pollution from cars and trucks}

The main pollution from road traffic is nitrogen dioxide (NO2). The latter irritates the respiratory tract, causes respiratory and cardiovascular diseases, and is highly carcinogenic. In 2017, the French car fleet numbered more than 39 million vehicles (INSEE, 2017). It consists of passenger cars (83\% of the total) and heavy goods or passenger vehicles (17\% of the total). Diesel engines, which used to be the vast majority, have been steadily declining in recent years as a result of government action. Since 2017, they have accounted for just under half of the total vehicle fleet, but remain dominant in freight transport.

In 2016, land freight transport amounted to 338.5 billion ton/kilometers (Commissariat Général au Développement Durable, 2018, 28). Its upward trend is based on road transport, French and - even more so - foreign. The registration of heavy goods vehicles is also increasing sharply and the average journeys they make are getting longer. At the same time, rail and inland waterway transport are decreasing.

\subsection{Pollution measurement}

The transport sector, particularly road transport, is strongly responsible for the increase in energy consumption in France and the emission of pollutants and greenhouse gases (GHGs). It consumes $82 \%$ of petroleum fuels in 2016 and accounts for nearly 30\% of GHG emissions (compared to $22 \%$ in 1990). These GHG emissions have been increasing in the transportation sector in recent years (Office of the Commissioner General for Sustainable Development, 2017, 12-13). Indeed, the improvement in the environmental performance of vehicles (fleet renewal, generalization of catalytic converters, etc.) does not compensate for the increase in the total number of kilometers travelled on the road. Heavy goods vehicles are responsible for more than 
one-fifth (21.3\% in 2016) of GHG emissions, while they represent only one-twentieth $(5.2 \%)$ of road traffic (ibid.). Finally, diesel-powered vehicle engines are responsible for $84 \%$ of GHG emissions in the road transport sector, whereas they now account for only about half of the vehicle fleet, after having long been its core.

\subsection{The question of diesel and "dieselgate"}

Gasoline and diesel are two products of petroleum distillation but with different chemical properties. While gasoline is a mixture of light hydrocarbons, diesel blends heavier hydrocarbons that cause much more pollution to fine particles, the latter being the most dangerous to the respiratory and cardiovascular systems of the human body. But the discovery and awareness of the problem of fine particle pollution is recent, and can be dated from a report by the International Agency for Research on Cancer in 2012 (Pasteau, Perez, Teulière, 2015). However, it was in the early 1980s that France decided to give priority to diesel engines for passenger cars, by taxing them less. The government's aim at the time was to favour a technique that would give the French automobile industries an advantage in the now global competition, as well as to satisfy the demands of the oil industry, which was concerned about the widespread use of electric heating to the detriment of oil heating (the latter being a poorly distilled product with characteristics very similar to diesel fuel). Buses and trucks, on the other hand, had long been diesel-powered. As a result, diesel accounted for up to $70 \%$ of French car sales in the early part of 2010 .

Faced with the fact that technological innovations (such as particulate filters) can only marginally reduce the pollution caused by diesel engines, the public authorities have undertaken to varying degrees to gradually reduce this proportion. Certainly, it seems that there is only one example of a region in the world that has totally eradicated diesel engines: the city of Tokyo in Japan (Pasteau, Perez, Teulière, 2015, 9). But restrictive standards and disincentive taxes are multiplying throughout the European Union (Euro standards). Especially as scientific studies are accumulating to overwhelm this technology. In May 2017, researchers estimated in the journal Nature that nitrogen oxide pollution from diesel engines was probably responsible for nearly 40,000 deaths worldwide in 2015 (Anenberg et al., 2017). One major obstacle remains: the resistance of European industrialists, who have long based part of their financial success on diesel and have resorted to criminal practices to preserve it.

It was in 2015 that Dieselgate broke out, when the US Environmental Protection Agency revealed that the German group Volkswagen, the world's leading car manufacturer (also owner of the Audi, Skoda, Seat and Porsche brands), with a turnover of nearly 240 billion euros at the 
time, massively evaded the approval tests of its vehicles to hide polluting emissions. In France, the Directorate General for Competition, Consumer Affairs and Fraud Control (DGCCRF), seized of the problem, launched a "survey on the practices relating to nitrogen oxide (NOx) emissions of a dozen car manufacturers marketing diesel vehicles in France", including the two largest French manufacturers. In November 2016, it announced that it would report to the courts the results of its investigation into the Renault group (the fourth largest in the world in terms of turnover), which was also suspected of having used software designed to distort pollution test results in order to obtain the necessary approvals for marketing in Europe. The French agency added that this "fraudulent strategy" had probably lasted since 1990 and that it involved the entire "management chain" of the group (Génération Nouvelles Technologies, 16 March 2017). Finally, in September 2017, the French agency revealed the result of its investigation into the PSA group (Peugeot-Citroën, the 9th largest group in the world in terms of turnover), which it also accused of "fraudulent strategy" and "deception" concerning the homologation tests of at least two million vehicles sold between 2009 and 2015, twice as many as those that were the subject of the first scandal at Volkswagen. Finally, it appears, on the one hand, that some groups such as Volkswagen have tried to put pressure on the media by threatening to reduce their advertising investments if they give too much coverage to the case, and on the other hand, that the main European car manufacturers have already begun to try to circumvent the new "WLPT" (Worldwide Harmonised Light Vehicle Test Procedure) standards set up by the European Commission following the first scandal. We can therefore speak here of a "normalization of deviance" in the sense that, in the culture of the companies concerned, managerial norms clearly dominate legal norms (Aggeri, Saussois, 2017, 93-94). The analysis of Volkswagen's delinquent practices also highlights the fact that they are all the more widespread since state regulatory authorities have so far used the law only as a mediation tool in "a certain management of illegalisms made up of collusion and accommodation relations between the regulator and the regulated" (ibid., 85).

\subsection{Industrial pollution}

The problem is very old and the historiography of industrial risks has developed considerably in recent years (Centemeri, Daumalin, 2015; Le Roux, 2016; Massard-Guilbaud, 2010; Charvolin et al., 2015). Smoke, gas and smells have been a cause for concern since the strong development of the industry in the 18th century and led to regulations at the beginning of the 
19th century. However, it was not until the 1980s - in the context of growing concern for the environment and political ecology, and the global repercussions of the Seveso (1976), Bhopal (1984) and Chernobyl (1986) disasters - that environmental epidemiology and toxicology studies multiplied, linking industrial pollution to a number of diseases, particularly respiratory ones. Meanwhile, massive industrialization in some regions has caused health disasters that still affect the surrounding populations today. Few examples have really been studied over time (Marichalar, 2017). And the quantification of occupational diseases is still in its infancy in France, with the exception of asbestos, which constitutes more than $80 \%$ of cancers recognized as being of occupational origin (Conseil d'orientation sur les conditions de travail, 2015, 221). However, there is no doubt about the situation of many major industrial sites.

\subsubsection{The example of Fos-sur-Mer and the Etang de Berre}

The geographical analysis proposed by the experts from France Santé Publique (2016) first indicates that pollution is higher in large urban areas: the Paris region, the north-east and the Lyon-Marseille axis. But many rural and even suburban areas are also heavily polluted due to industrial activity. We will remember here the example of the Marseille region, around the Etang de Berre. Several municipalities are particularly affected by the effects of pollution, located a few tens of kilometres northwest of Marseille, around the mouth of the Rhône and the Mediterranean coast: Fos-sur-Mer (approx. 16,000 inh.), Port-de-Bouc (approx. 17,000 inh.) and Port-Saint-Louis-du-Rhône (approx. 9,000 inh.) south of the pond, Berre (approx. 13,500 inh.) and Rognac (approx. 12,000 inh.) in the northeast.

In the early 1970s, France decided to set up a huge industrial port area in Fos-sur-Mer, in a mixture of the ideology of progress by industry, Parisian technocracy and the denial of environmental and health issues (although already largely known at the time: Perrin, 1974). Some dream of seeing the birth of "French California" at the dawn of "the year 2000" (Paillard, 1981, 44). The municipality will then gradually cover itself with refineries, oil depots, chemical, metallurgical and steel plants, industrial and household waste treatment plants, cement plants and LNG terminals. On a territory that nowadays has about fifty industrial installations, three major and highly polluting activities are still present. First, metallurgy with the steel giant Arcelor Mittal, a group based in Luxembourg, the world's leading steel producer, whose turnover reached 80 billion dollars in 2013. Then there is oil refining with Esso, the French subsidiary of the American oil group Exxon-Mobil, which is one of the ten most profitable companies in the world, with a turnover higher than most countries in the world (nearly $\$ 440$ 
billion in 2013). Finally, petrochemicals, with the American multinational Lyondell-Basell in particular.

However, it appears that the factories of at least two of these three groups pollute, while trying to hide it from the public eye, regularly committing offences, again allowing us to talk about routine delinquent activity or organized delinquent practices. Dozens of various problems (exceeding pollution standards, repeated incidents, delays in safety work to be carried out, etc.) have been reported by the public authorities concerning Arcelor Mittal's plants ${ }^{1}$. The problem is even more serious in the case of the petrochemical group Lyondell Chimie France, which handles in particular butanol and propylene oxide for the production of polyurethanes (chemical components used to manufacture plastics found in countless materials and in most objects of everyday life). However, these molecules are highly toxic and have a high risk of inflammation. Inhaling them is at best irritating, at worst carcinogenic. The same applies to the liquefied fuel gases manufactured and stored by the company, which are used in particular to manufacture ethers used in motor fuels.

On 21 October 2010, an inspection by the Regional Environment Directorate took place, which submitted its report on 8 August 2012. On 17 September 2012, the Bouches-du-Rhône prefecture sent the company a formal notice order, the reading of the "recitals" of which is instructive:

« Considering that LYONDELL Chimie France operates four boilers for its steam needs at its Fos-sur-Mer site;

Considering that during his on-site visit, the Classified Facilities Inspector found that the company had not complied with the applicable regulatory values for air emissions from its boilers since 2009 and that the applicable dust concentration limit at the boilers was regularly exceeded;

Considering that the operator does not comply with the applicable requirements and that the exceedances observed have persisted for several years ».

Did Lyondell subsequently change its behavior? This is not the case. In 2014, the "hazard study" revealed persistent problems. The prefectoral decree of 9 April 2014 specifies that "the operator's control of the risks related to his activity does not seem sufficient" and prescribes a series of measures to be taken. At the Berre-l'Étang site, huge quantities of liquefied flammable gases are stored, presenting major health risks in the event of a leak or fire. The law therefore requires the industrial company to equip its site with adequate detection and alarm systems, which it is reluctant to do. The prefectoral decree of formal notice of 16 September 2015 notes

\footnotetext{
1 See this company's file on the classified installations website: www.installationsclassees.developpementdurable.gouv.fr/ ("établissement $\mathrm{n}^{\circ} 1052$ "). All the administrative decisions that follow in this paragraph are taken from this site.
} 
this time that, despite the instructions given following inspections and numerous exchanges of letters, the manufacturer has not taken "these technical measures[which] contribute to the prevention of major accidents that could lead to lethal effects on the establishment's environment".

Finally, the companies of the Lyondell-Basell group do not only pollute the air, but also the water. The problem has been recognized at least since 2010. However, it persists, as the company refuses to undertake the sealing work necessary to secure its pipes. On 16 March 2018, the Préfecture des Bouches-du-Rhône issued a new formal notice order against the petrochemical group concerning the Berre-l'Étang site, concerning the pollution of groundwater aquifers to the northwest of the municipality. In passing, the decree noted that "some leaks have been identified for more than 9 years without any sealing work carried out since then".

\subsubsection{The health threat: accumulation and convergence of strong indicators}

There is no systematic data collected on the occupational diseases of people working on these polluting industrial sites, only a series of testimonies centred solely on the employees of these companies and not on their countless subcontractors (Grandmaison, 2017, 31sqq). On the other hand, the consequences of industrial pollution around the Étang de Berre on the respiratory and cancerous pathologies of the surrounding populations have been known by health institutions for several years, albeit in an incomplete way. In particular, it is established that women are at a much higher risk of myocardial infarction than in the average of equivalent municipalities and that men are at two and a half times higher risk of acute leukemia (Pascal Bensa et al., 2012), even though the study studied only two polluting agents. In general, local data have long been lacking and populations (as well as local doctors who regularly report in the press on alarming levels of certain diseases in their patients) have been kept not only in ignorance, but also in contempt for their fears and daily illnesses, including by public authorities. Strangely, the Regional Health Observatory (ORS PACA) has never conducted a diagnosis on the Commune of Fos-sur-Mer. Only on its website is a summary study of the neighboring municipality of Port-Saint-Louis du Rhône, which nevertheless establishes a very significant excess mortality compared to the region in terms of respiratory tract diseases $(+77.3 \%$ compared to the regional average) and cancers (+31.9\%), in particular lung cancers (+61.8\%) (Dumesnil, Saugeron, 2013 , 12). This is all the more surprising as the statistical data on the causes of mortality, available on its community-wide information system, clearly suggest a concentration of 
problems, particularly deaths from lung cancer, in several municipalities in the Étang de Berre where industrial sites are concentrated (Table 1).

Table 1 : comparative mortality indices (CMI) in four communes in the Bouches-du-Rhône

\begin{tabular}{|l|c|c|c|c|}
\hline & Fos-sur-Mer & Port-de-Bouc & $\begin{array}{c}\text { Port-Saint- } \\
\text { Louis-du-Rhône }\end{array}$ & Berre \\
\hline All causes & 109 & 113 & 115,3 & 113,5 \\
\hline Premature & 99,9 & 130 & 121,8 & 120,2 \\
\hline Preventable & 103,1 & 139,1 & 117,2 & 116,1 \\
\hline Cancer & 121,6 & 121,3 & 114,3 & 129,2 \\
\hline Lung cancer & 136,8 & 151,3 & 108,6 & 178,8 \\
\hline Regional average & 100 & 100 & 100 & 100 \\
\hline
\end{tabular}

Source: Inserm-CépiDC, 2009-2013; SIRSéPACA «portraits de territoires socio-sanitaires »[en ligne]; author's calculations

Faced with this lack of diagnosis, however, local mobilizations have made it possible to include in the file studies that are certainly partial, but with significant and totally convergent results. Three studies, based on three forms of civil mobilization, were published in the space of three years, in addition to a study carried out by a State agency.

First, in 2015, participatory scientific research was conducted to describe individual health problems based on the study of a randomly selected population of 816 individuals or households, constituting a representative sample of the population of the municipalities of Fossur-Mer and Port-Saint-Louis-du-Rhône (Allen, Cohen, Ferrier, Lees, 2017). Its results indicate that the population suffers much more than the average from asthma (mainly men), cancers (mainly women, breast and uterine cancers) and diabetes. In total, nearly two thirds of the population reports at least one chronic disease (asthma, other respiratory disease, respiratory allergy other than pollen, dermatological disease, cancer, autoimmune disease, endocrine disease and/or diabetes), almost twice the French average. About two thirds are also affected by a chronic symptom (eye irritations, nose/throat symptoms, headache, skin problems, nose bleeds). On a geographical scale, it appears that some districts are even more affected than others because they are located closest to industrial installations and are most exposed to breathing polluted air regardless of the direction of the winds. In these neighborhoods, it is the health of the entire population that is globally threatened by industrial pollution.

Then, at the end of January 2018, Air Paca (an air quality monitoring association approved by the Ministry of the Environment) published the results of a study aimed at "quantifying, using risk indicators, the impact of air pollution on health". The report states that "the use of this tool 
in the Étang de Berre region has made it possible to identify the areas for which management thresholds are exceeded, for the first time in such an approach, by integrating 39 substances and all sources of pollution (industry, transport, heating, ships, etc.) on the scale of a territory composed of 66 municipalities" (Air Paca, 2018, 2). The study first concludes that there are pollutants related to road and highway traffic, as well as an airport, as in other regions. But it adds that, for other pollutants, the exceedances of the observed risk management thresholds are "specific to the study area[...] around the Gulf of Fos, Martigues and Berre where many industrial activities are present" (ibid., 23). In concrete terms, in Fos, Martigues and Berre, three molecules linked to industrial activity pose a risk to the health of the population with regard to certain cancer diseases. And recognizing it was a first for a government department that was often criticized by local associations.

A few days later, in February 2018, the "Association de défense et de protection du littoral du golfe de Fos" (created in 2002 by a small group of inhabitants) has organizing a public meeting to reveal the results of a study it had carried out on a series of food products from the Gulf of Fos: bull, sheep, goat cheese, chicken eggs, fish, mussels, olive oil and hay (ADPLGF, 2018). Two specialized and independent laboratories searched the samples for about 50 chemical compounds. Then the "Institut écocitoyen pour la connaissance des pollutions" (IECP, see below) and its scientific council interpreted the results. The latter are of particular concern in the case of bull meat and eggs, where very high concentrations of dioxins (carcinogens) and polychlorinated biphenyls (endocrine disrupters) have been found. Seafood products, on the other hand, revealed a significant presence of heavy metals (lead, cadmium). As a result, "the association, supported by the town hall of Fos-sur-Mer, decided, after fifteen years of alerts, to transmit to the courts with the filing of a complaint against $\mathrm{X}$ for endangering the lives of others" (Mandard, 2018).

Finally, in May 2018, another local initiative replaced the apathy of the health authorities. The IECP, created in 2010 by local authorities and led by academics, submitted a report presenting the results of a "study on the impregnation of the population with atmospheric pollutants in the Fos-sur-Mer industrial port area" (IECP, 2018). After a telephone survey, 138 people aged 30 to 65 were interviewed face-to-face between September and November 2016 in the commune of Fos and in a commune $20 \mathrm{~km}$ away in order to compare. Urine and blood samples were systematically taken. The pollutants sought were metals, polycyclic aromatic hydrocarbons, benzene, PCBs and 17 dioxins/furans considered to have significant toxicity. The study confirms that the presence of pollutants is mainly linked to food (consumption of seafood, garden vegetables) and lifestyle (activities such as gardening increases exposure to pollutants), 
but it shows that these daily ordinary activities are precisely made more risky in the municipality located in an industrial zone. The measures show "an over impregnation of the population exposed by inhalation for lead, two furans typical of industrial emissions, and benzene but only in the oldest people". She pointed out that "gardening in the exposed area was associated with an increase in total PCB impregnation compared to the control area", that "consuming garden vegetables was associated with an increase in cadmium impregnation in the exposed area, while the effect was protective in the control area" and finally that "the consumption of local seafood was associated with an increase in PCB, dioxins/furans, mercury and chromium impregnations". Again, the study is limited due to low enrolment and the lack of recent comparative national data. However, it is a strong and converging third index.

\section{Provisional conclusions: further research on corporate crime}

The issues raised in this article echo the debates that have occupied the sociology of crime and criminology for the past twenty years or so in England and North America. They are only just beginning to be investigated in France, where it is difficult to emerge from a phase where political-media "scandals" probably tend to polarize opposing attitudes of radical dramatization or euphemism. The environmental and health problems mentioned in this text are, however, old and their origins known. So it is rather their persistence that surprises, or even their resistance, given the increasing scale of mobilizations and regulations aimed at combating them (Jaworski, 2009; Neyret, 2015). Certainly, at the international level, it is easy to understand how national egoisms threaten to ruin the efforts of scientists at any time. The story is not new (Boudia, Henry, 2015; Aykut, Dahan, 2015). Recently, the hope raised by the collective commitments made at COP 21 in December 2015 in Paris quickly turned into disillusionment after the 2016 US presidential elections. However, at the national level, with the themes of environmental protection and public health generating a broad political consensus, one would expect rapid and important developments. However, this is hardly the case. In the report of a Senate committee of inquiry on air pollution, the parliamentarian who led it clearly expressed this feeling of powerlessness: "Why such a delay between the level of scientific knowledge (physical, biological, medical, economic) and political decision-making on air pollution? (...) Your committee of inquiry can only note the failure of the measures taken over the past twenty years (...). More seriously, your committee of inquiry notes that the same measures are being proposed, studied, not applied, forgotten and then proposed again" (Senate, 2015, 13). These findings are an invitation to investigation for the social sciences. 
Indeed, political science research highlights the contradictions and opacities surrounding the concrete implementation of public policies: "the management of many issues (such as shale gas or pesticides) shows the gulf between the principles of openness and many administrative and political practices that remain discretionary" (Lascoumes, 2012, 125). The role of administrative officers of control bodies in the management of health alerts (Jouzel, Prete, 2017) and more broadly in clarifying the issues and conflicts surrounding the production of health and environmental expertise (Henry et al., 2015; Counil, Henry, 2016) are just beginning to be studied. Research is also in its infancy as to the role of local elected officials, who can disrupt polluters by joining forces with state control agents or, on the contrary, enter into "logics of shared governance and territorialized regulation" with industry (Fournier, Mattina, 2013). Moreover, traditional trade unions seem, for the time being, to be very little mobilized in France on environmental issues such as industrial pollution, unlike what can be observed in other countries. The issue of whistleblowers and their protection has not yet been studied in this area. As for citizen mobilizations, without the assistance of the State or local elected officials, they are inevitably powerless and remain generally scattered and ephemeral (Calvez, 2016). As for the sociology of delinquency, there are still many areas to be investigated. As for industrial practices, it would be important to be able to analyze strategies for "securing delinquent practices" (Speyer, 2013) as well as strategies for resisting pressure from States, the media and citizen mobilization. On the administrative side, questions arise in particular about the nature, effectiveness and efficiency of controls and sanctions carried out by the State and its law enforcement institutions in all the areas concerned (police, justice, labor inspectorates, tax officials, bodies responsible for monitoring compliance with health and environmental standards, etc.). But beyond this identification of hidden weaknesses in the implementation of public policies and the handling of health warnings, two other "macro" phenomena probably play a decisive role in understanding the permanence of problems whose diagnosis seems established.

The first is the gradual concentration of companies that has been taking place since the 1970s in most economic sectors, in connection with the financialization and globalization of markets, leading to the creation of multinationals whose turnover is higher than that of most countries in the world (Bauchet, 2007; Chavagneux, Louis, 2018). Faced with economic giants who are weighing more and more heavily in every respect (and can exert more than ever various forms of blackmail on employment and investment on States), it is understandable that public authorities are experiencing major difficulties in the negotiations required to adopt new, more stringent production standards. However, most of the management of major risks is still played 
out in this balance of power between government services and industry (Bonnaud, Martinais, 2008). It is also understood that it is in return much easier to make individuals feel guilty and tax them (Boutaric, 2014).

This concentration also gives these economic groups - and this is the second phenomenon - a tenfold increase in power in terms of lobbying, corruption and crime. As we have seen in the two examples of industrial pollution developed, these practices have never disappeared. And they are found almost systematically in the analysis of health and environmental disasters, for example in the pharmaceutical industry or the agri-food industry (Mucchielli, 2018). In France, one may even wonder whether they are not particularly strong because of the high level of collusion between the world of political leaders from the "grandes écoles" (in particular the National School of Administration [ENA] and high engineering schools, what Bourdieu [1989] called the "noblesse d'État") and that of economic leaders, collusion which is reflected in particular in common practices of "slipping" (Bouzidi et al., 2010; Rouban, 2010) as well as recurring problems of conflicts of interest and corruption. The case of the Ministry of Health and Pharmaceutical Industry is now well known, but it is far from being the only one (ThébaudMony, 2014; Lenglet, Touly, 2015). Far from being reduced, the "scrambling" is in fact increasing between the defense of the general interest and that of private interests (France, Vauchez, 2017; Cassia, 2018). It is therefore highly likely that this only perpetuates the relative impunity enjoyed by certain industrial groups that daily degrade the environment and the state of health of populations.

\section{Bibliographie}

ADPLGF, 2018, Rapport de la campagne d'analyses pilotée par l'Association ADPLGF sur des produits alimentaires du pourtour du Golfe de Fos, Fos-sur-Mer, Association de Défense et de Protection du Littoral du Golfe de Fos [en ligne].

Aggeri F., Saussois J.-M., 2017, «La puissance des grandes entreprises mondialisées à l'épreuve du judiciaire. De l'affaire Volkswagen au dieselgate », Revue française de gestion, 269 (8), 83-100.

Air Paca, 2018, Simulation de scénarii de pollution atmosphérique pour une Évaluation des Risques Sanitaires. Application à la région de l'Étang de Berre, Marseille, Air Paca [en ligne]. 
Allen B., Cohen A., Ferrier Y., Lees J., 2017, Étude participative en santé environnement ancrée localement sur le front industriel de Fos-sur-Mer et Port-Saint-Louis-du-Rhône, Marseille, Centre Norbert Elias [en ligne].

Anenberg S., et alii., 2017, «Impacts and Mitigation of excess diesel-related $\mathrm{NO}_{\mathrm{x}}$ emissions in 11 major vehicle markets », Nature, 545, 467-473.

Aykut S., Dahan A., 2015, Gouverner le climat? 20 ans de négociations internationales, Paris, Presses de Sciences-Po.

Baucher P., 2007, Concentration des multinationales et mutation des pouvoirs de l'État, Paris, CNRS éditions.

Bonnaud L., Martinais E., 2008, Les leçons d'AZF. Chronique d'une loi sur les risques industriels, Paris, La Documentation française.

Bottoms T., 1994, « Environmental Criminology », in Maguire M., Morgan R., Reiner R. (dir.), Oxford Handbook of Criminology, Oxford, Oxford University Press, 585-660.

Boudia S., Henry E. (dir.), 2015, La mondialisation des risques. Une histoire politique et transnationale des risques sanitaires et environnementaux, Rennes, Presses Universitaires de Rennes.

Bourdieu P., 1989, La noblesse d'État. Grandes écoles et esprit de corps, Paris, Minuit.

Boutaric F., 2014, Pollution atmosphérique et action publique, Paris, Éditions rue d'Ulm.

Bouzidi B. et al., 2010, «Le pantouflage des énarques : une première analyse statistique », Revue française d'économie, 25 (3), 115-146.

Buttel F. H., 1978, « Environmental Sociology. A new Paradigm?», The American Sociologist, $13,252-256$.

Calvez M., 2016, « Les risques de santé à l'épreuve des nuisances. Le cas des plaintes en santé environnementale », Recherches sociologiques et anthropologiques, 47 (1), 187-203.

Catton W. R., Dunlap R. E., 1979, « Environmental Sociology », Annual Review of Sociology, $5,243-273$.

Cassia P., 2018, «La perméabilisation en marche des activités publiques et privées », Mediapart [en ligne], 30 mars 2018 (URL: https://blogs.mediapart.fr/paulcassia/blog/300318/la-permeabilisation-en-marche-des-activites-publiques-et-privees).

Centemeri L., Dumalin X. (dir.), Pollutions industrielles et espaces méditerranéens. XVIIIèXXIè siècle, Paris, Khartala.

Charvolin F., Frioux S., Kamoun L., Mélard F., Roussel I., 2015, Un air familier ? Sociohistoire des pollutions atmosphériques, Paris, Presses des Mines. 
Chavagneux C., Louis M., 2018, Le pouvoir des multinationales, Paris, Presses Universitaires de France.

Collectif, 2010, «Santé et travail », Politix. Revue des sciences sociales du politique, $\mathrm{n}^{\circ} 91$.

Commissariat général au développement durable, 2017, Les comptes des transports en 2016, Tome 1. Paris, Ministère de la transition écologique et solidaire.

Commissariat général au développement durable, 2018, Chiffres-clés du transport. Edition 2018, Paris, Ministère de la transition écologique et solidaire.

Conseil d'orientation sur les conditions de travail, 2015, Conditions de travail. Bilan 2014, Paris, Ministère du Travail, de l'Emploi, de la Formation professionnelle et du Dialogue social.

Counil É., Henry E., 2016, « Produire de l'ignorance plutôt que du savoir ? L'expertise en santé au travail », Travail et emploi, 148 (4), 5-29.

Dumesnil H., Saugeron B., 2013, Port-Saint-Louis-du-Rhône. Premiers éléments de diagnostic, Observatoire Régional de la Santé PACA, série « Diagnostic de territoire ».

Fournier P., 2012, Travailler dans le nucléaire. Enquête au cœur d'un site à risques, Paris, Armand Colin.

Fournier P., Mattina C., 2013, « Secours ou entrave à l'action publique ? Les élus locaux face à l'État dans les territoires mono-industriels à risques », Sciences de la société, 90, 129148.

France P., Vauchez A., 2017, Sphère publique, intérêts privés. Enquête sur un grand brouillage, Paris, Presses de Sciences Po.

Gilbert C., Henry E., 2009, Comment se construisent les problèmes de santé publique. Paris, La Découverte.

Grandmaison de J., 2017, Polluants industriels. Salariés en danger, Paris, Editions de l'Atelier. Hall M., Wyatt T., South N., Nurse A., Potter G., Maher J., 2016, Greening Criminology in the 21 st Century. Contemporary debates and future directions in the study of environmental harm, London, Routledge.

Henry E., Gilbert C., Jouzel J.-N., Marichalar P. (dir.), 2015, Dictionnaire critique de l'expertise. Santé, travail, environnement, Paris, Presses de Sciences-Po.

IECP, 2018, Étude INDEX. Étude d'imprégnation de la population aux polluants atmosphériques de la zone industrialo-portuaire de Fos-sur-Mer. Rapport d'étude, Fossur-Mer, Institut Eco-citoyen pour la Connaissance des Pollutions.

Jaworski V., 2009, «L'état du droit pénal de l'environnement français : entre forces et faiblesses », Les Cahiers de droit, 50 (3-4), 889-917. 
Jouzel J.-N., 2012, Des toxiques invisibles. Sociologie d'une affaire sanitaire oubliée, Paris, Éditions de l'EHESS.

Jouzel J.-N., Prete G., 2017, «La normalisation des alertes sanitaires. Le traitement administratif des données sur l'exposition des agriculteurs aux pesticides », Droit et société, 96 (2), 241-256.

Lascoumes P., 2012, Action publique et environnement. Presses Universitaires de France.

Lascoumes P., Nagels C., 2014, Sociologie des élites délinquantes, Paris, Armand Colin.

Le Moullec A., 2016, Bilan de la qualité de l'air en France en 2015, Paris, Ministère de l'environnement.

Lenglet R., Touly J.-L., 2015, Les recasés de la République, Paris, éditions First.

Le Roux T., (dir.), 2016, Risques industriels. Savoirs, régulations, politiques d'assistance, fin XVIIe-début XXe siècle, Rennes, Presses Universitaires de Rennes.

Marichalar P., 2017, Qui a tué les verriers de Givors ? Une enquête de sciences sociales, Paris, La Découverte.

Massard-Guilbaud G., 2010, Histoire de la pollution industrielle en France, 1789-1914, Paris, Éditions de l'EHESS.

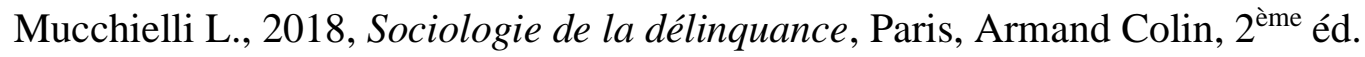

Mucchielli L., 2015, «L'ampleur et l'étendue de la délinquance des élites », in Bonfils P., Mucchielli L., Roux A. (dir.), Comprendre et lutter contre la corruption, Aix-en-Provence, Presses de l'Université d'Aix-Marseille, 33-48.

Neyret L. (dir.), 2015, Des écocrimes à l'écocide. Le droit pénal au secours de l'environnement, Bruxelles, Bruylant.

Paillard B., 1981, La damnation de Fos, Paris, Seuil.

Palidda S. (dir.), 2016, Governance of security and ignored insecurities in contemporary Europe, London, Routledge.

Pascal Bensa L, et al., 2012, «Pollution atmosphérique et hospitalisations pour pathologies cardiovasculaires, respiratoires et pour cancers, dans le secteur de l'Etang de Berre, 20042007 », Revue d'épidémiologie et de santé publique, 60, supplément 1.

Pasteau E., Perez B., Teulière E., 2015, Le Diesel : enjeux économiques, politiques publiques, comparaison internationale, Paris, CERES-ERTI [en ligne]

Perrin R., 1974, «Fos et l'environnement », Méditerranée, 18 (3), 41-56.

Rouban L., 2010, «L'inspection générale des Finances, 1958-2008 : pantouflage et renouveau des stratégies élitaires », Sociologies pratiques, 21 (2), 19-34. 
Santé Publique France, 2016, Impacts de l'exposition chronique aux particules fines sur la mortalité en France continentale et analyse des gains en santé de plusieurs scénarios de réduction de la pollution atmosphérique, Saint-Maurice, Santé Publique France.

Sénat, 2015, Rapport fait au nom de la commission d'enquête (1) sur le coût économique et financier de la pollution de l'air, Paris, Sénat, Rapport nº610.

Spire A., 2013, « Pour une approche sociologique de la délinquance en col blanc », Champ pénal/Penal field [En ligne], Vol. X|2013, mis en ligne le 28 juillet 2013. URL: http://journals.openedition.org/champpenal/8582

South N., 1998, «Corporate and State Crimes Against the Environment. Foundations for a Green Perspective in European Criminology », in Ruggiero V. South N., Taylor I. (eds.), The New European Criminology, London, Routledge, 443-461.

Terssac de G., Mignard J., 2011, Les paradoxes de la sécurité. Le cas d'AZF, Paris, Presses Universitaires de France.

Thébaud-Mony A., 2014, La science asservie. Santé publique : les collusions mortifères entre industriels et chercheurs, Paris, La Découverte.

Thébaud-Mony A., Daubas-Letourneux V., Frigul N., Jobin P., 2012, Santé au travail : approches critiques, Paris, La Découverte. 